\title{
Socio-economic Factors and Adoption of ICT among staff members of Colleges of Education in Northwest zone of Nigeria
}

\author{
Isaac Olugbemiga Ogunleye, $\mathrm{PhD}$ \\ Department of Business Education, Federal College of Education, PMB 3045, Kano, Nigeria.
}

This research is financed by Tertiary Education Trust Fund (TETFUND), Nigeria

\begin{abstract}
This study examined the impact of socio-economic characteristics on ICT adoption by staff members in the fourteen (14) colleges of education located in northwest geo-political zone of Nigeria. A cross-sectional form of descriptive survey design was adopted. Though the population of this study was 15,219 , comprising 5,845 and 9,374 academic and non-academic staff respectively a sample of 610 was used. A combination of simple random and stratified random sampling techniques was used to select the sample and data was collected through a selfcompletion structured questionnaire. Multiple linear regression model was used to test the main alternate hypothesis of the study at 95 per cent confidence level. Data analysis revealed that socio-economic variables have significant influence on IT adoption. Specifically, each of income, level of education, access to technology, age, gender and ownership of technology are predictors of level of ICT adoption. However, variables such as place of training, time of training, educational discipline and work experience do not have significant influence on the level of IT adoption. Hence, it was recommended that institutional heads should consider sales, training and maintenance agreement with hardware producers and software developers for the benefits of staff members. Employees should be encouraged to have access to expertise in data processing, graphics and publishing packages.
\end{abstract}

Keywords: Adoption, Diffusion, Innovations, socio-economic characteristics, Information Technology, educational institutions, staff members

DOI: $10.7176 / \mathrm{IKM} / 9-2-07$

\section{Introduction}

Evolving developments in Information and Communication Technology (ICT), or Information Technology (IT) have led close watchers to welcome the arrival of a third age of computing in which the technology devices themselves are being overshadowed by the communications capabilities they provide individuals and organizations. In this twenty-first century, Information and Communication Technology (ICT) is becoming increasingly important to the development and execution of corporate strategies in Nigeria, and ICT is being increasingly applied in the search for competitive advantage across the globe (Kotler and Keller, 2013). This has made ICT to be seen not just as a useful tool for management but also something that represented a strategic challenge for them to manage. Therefore, every individual who wants to excel in his/her chosen career must embrace this reality, as 'information is power' and whoever has access to it gets power. Educational institutions are 'information dissemination and exchange centres' and the crucial role of ICT in this direction has come to stay with all members of these institutions. As such, the importance of computer-related devices as media for providing effective college management, effective teaching and learning activities and for providing information to researchers and scholars is obvious. Interestingly, the availability of Internet facilities in academic institutions offers a wide range of access to information globally without geographical barriers. In other words, every member of an organization now has unlimited access to all facets of information, but knowledge of IT usages places limit on one's access to information and information is knowledge!

It is not difficult to convince discerning minds that teaching and learning in tertiary educational institutions is undergoing a technological revolution. In Nigeria, the dire need to bridge the digital divide and for the nation to effectively join the emerging global economy, driven by information and communication technologies necessitated the establishment of the National Information Technology Development Agency (NITDA). The Nigerian National Information Technology Policy was approved by the Federal Executive Council (FEC) in March 2001 and NITDA took-off in April, 2001. One of its aims is to operationalize the National IT Policy; to 
ensure that the entire citizenry is sufficiently empowered with information technologies (FGN, 2004). One of the National IT strategic plans is the computerization of schools which involves the establishment of computer laboratories with internet connectivity in all Federal Government Colleges. It is aimed at exposing the students to practical computer education and building capacity in ICT in order to produce globally competitive youth (FGN, 2004).

In view of the above, educational planners are now under pressure more than ever before to invest resources to move their institutions towards more technology-based approaches to teaching and learning. Higher education news is rich with claims about the power of ICT to revolutionise teaching and learning within tertiary educational institutions. However, terminology may at this stage emerge as a difficulty when discussing the use of ICT in teaching. Based on Rogers' diffusion of innovation theory, two sets of variables namely, technology ownership and adopters' characteristics have enduring impacts on the adoption of new technologies (Lii, 2013). In this research, the two sets of variables were taken into consideration in examining the adoption of IT by staff members of Colleges of Education in Northwest zone of the country.

This study focused on staff members in colleges of education in Northwest zone of Nigeria. Staff members of these institutions were taken to include teaching and non-teaching staff. Also, consideration of IT adoption by members of these educational institutions was delimited to computer (PCs and laptops) and hand-held mobile phones. Information Technology adoption was delimited to the use of these devices for all administrative and academic activities including teaching and research.

\section{$1.1 \quad$ Justification/Significance of the Study}

In Nigeria, the evolution, development and advances in modern ICT have brought in a dramatic and an unprecedented revolution in information management and services, especially as it affects teaching and research activities in tertiary educational institutions. It is in recognition of this that tertiary educational institutions in Nigeria have begun to develop IT and information system strategies to deal with the need to respond to rapid changes in information technology which affect content of nearly every course curriculum.

Omoniwa (2001) traced the attempt to computerize Kashim Ibrahim Library at Ahmadu Bello University (ABU), Zaria, Kaduna state from 1972 to 2001 and discussed the problems that had militated against the computerization effort. Ani, Esin and Edem (2006) surveyed the adoption of ICT in Nigerian academic libraries and reported that only six libraries are fully computerized as at that time. Oketunji, Daniel, Okojie and Abdulsalam (2012) in their study were concerned with determining the state and future of ICT in libraries and information services in Nigeria. Omoniwa (2001) has posited that in the twenty-first century, globalization of information and early adoption of information technology will be the hallmark of great educational institutions.

The above notwithstanding, few literature exists only in the area of the effects of socio-economic characteristics on the ICT adoption in Nigerian universities while other categories of education in Nigeria tertiary institutions (such as Colleges of Education) lack empirical studies in this area. It is against these backdrops, that this study is embarked upon to assess the impact of socio-economic characteristics on the ICT adoption among staff in Colleges of Education in north-west zone of Nigeria.

The overall and unique contributions of socio-economic and individual characteristics (such as sex, age, income, educational qualification, educational discipline, length of working experience, etc) to ICT adoption/literacy level will be empirically established. Thus, findings will serve as inputs into Federal Government's policy on IT for tertiary educational institutions. The study can be benchmarked and replicated in other geo-political zones of the country and in other levels of tertiary educational institutions in the country.

\subsection{Objective of the Study}

The primary objective of this study was to assess and explain the effects and patterns of socio-economic characteristics on the adoption of Information and Communication Technology (ICT) adoption by staff members of Colleges of Education in Northwest zone of Nigeria.

\subsection{Research Hypothesis}

This study was guided by one alternate hypothesis which was tested at $95 \%$ confidence level:

$\mathrm{H}_{1}$ : $\quad$ Socio-economic characteristics (variables) make significant functional contribution to ICT adoption level by staff members in colleges of education. 


\section{Literature Review}

\subsection{Diffusion of Innovation and IT adoption models}

Diffusion of innovation, a theory applied mostly directly to communication studies by Rogers is the acknowledged starting place for studies attempting to describe implementation and use of new technology. Although originally based on the study of agricultural innovation, Rogers' diffusion theory has been the starting point for research within the fields of software and IT (Kautz and Larsen, 2012). The theory has been successfully used to explain problems concerning the diffusion and introduction of software development methods. As Rogers puts it, diffusion process is largely a communication process - an information seeking and processing activity.

According to Rogers (1995), the diffusion of innovation paradigm is particularly attuned to the interactions of social factors, organizational culture, communication patterns and information technology innovations. The theory explains and predicts the influence of a wide range of factors on the innovation adoption and implementation decision (Rogers, 1995). Rogers' diffusion theory consists of two processes - diffusion process and adoption process. Diffusion process and the adoption process are two closely related concepts. In the broadest sense, diffusion is a macro process concerns with the spread of a new product (an innovation) from its source to the consuming public. In contrast, adoption is a micro process that focuses on the stages through which an individual consumer passes when deciding to accept or reject a new product. According to the theory of diffusion of innovation advanced by Rogers, three sets of variables namely, technology ownership, adopter's characteristics and innovation attributes have enduring impacts on the adoption of new technologies.

Consequent upon the Rogers' diffusion of innovation, prominent IT adoption theories/models have been developed. The theory of planned behaviour proposed by Ajzen (1985) and which built on the earlier theory of reasoned action by Ajzen and Fishbeing (1980), added the idea of behavioural control, reflecting the individual's perception of the difficulty or ease of performing a particular behaviour. Though, it is acknowledged that such behaviours are affected, inter alia, by external resources, the theory neglects other factors that may also account for variance in behavioural intentions. Among the prominent IT adoption theories, Technology Acceptance Model (TAM) proposed by Davis, Bagozzi and Warshaw (1989) was the only one specifically developed with technology adoption in mind. Also, in Chuttur (2009), it was observed that although many models have been proposed to explain and predict the use of a system, the Technology Acceptance Model has been the only one which has captured the most attention of the Information Systems community. TAM posits that the adoption behaviours are determined by the intention to use a particular system, which is based on two key beliefs of (i) perceived usefulness and (ii) perceived ease of use. By perceived usefulness, a person believes that using a particular technology would help increase his performance whereas, perceived ease of use focuses on if a person believes the technology is easy to use and useful to him.

Another IT innovation adoption research model was developed by Agarwal and Prasad (1999) where they posit that IT innovation adoption comprises three stages: awareness, perception and adoption. They consequently proposed that awareness and perception are influenced by channel type on one hand, while perception and adoption are influenced by personal innovativeness on the other hand. Hence, it is obvious from this model that awareness is a key issue in the innovation adoption process.

By synthesizing various stages of innovation adoption process proposed by previous authors, Darmawan (2013) presented a four phase conceptual model of innovation adoption and implementation process. These four phase innovation adoption processes consist of initiation phase, adoption phase, implementation phase and evaluation phase. This four-phase innovation adoption process can also be observed at both the individual and organizational levels. The first level of adoption, organizational level adoption, starts when an organization begins to realise the need for strategic change (awareness) and decides to incorporate IT. It thus ends with acquisition of the technology. The second level of adoption, individual level adoption, commences with the acquisition of the technology, and finishes when the technology is utilized by the individual. These two levels fall within the purview of this study.

According to Yuandong and Tung (2006), the nagging question which relates to the factors that influence an individual's use of Information Technologies and how these factors influence IT usage behaviour, remain critical. Lakhanpal (2004) reviewed the literature on innovations in organizations and developed a framework which indicates that the use of IT is influenced by individual factors. Though individual differences are important to an understanding of technology usage behaviour, IT adoption models, such as technology acceptance model (Davis, 1989), have not paid sufficient attention to individual difference variables. At least two research streams can be identified from how individual differences combine with perception to influence technology use. The first stream 
(figure 1a) posits that individual differences influence technology use indirectly through perceptions (Davis, Bagozzi and Warshaw, 1989 and Agarwal and Prasad, 1999), and it is based on the theory of reasoned action (Ajzen and Fishbein 1980). The second research stream (figure 1b) argues that individual difference variables may moderate the relationships between perceptions and technology use (Venkatesh and Davis, 2000). Consistent with Agarwal and Prasad's (1999) IT Innovation Adoption Research Model, individual difference variables include demographic and situational variables that account for differences attributable to circumstances such as experience and training. Consequently, the following individual variables were identified in this study as variables of interest, i.e. age, income, educational qualification, educational discipline, place and time of training, working experience, access to technology and ownership of IT facilities.

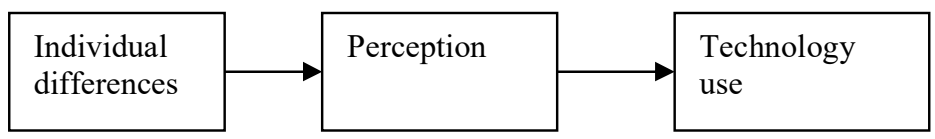

Figure 1a: First Research Stream and Conceptual Model I

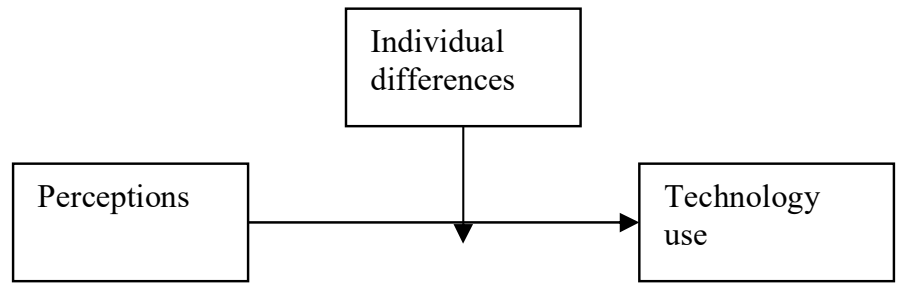

Figure 1b: Second Research Stream and Conceptual Model II

Source: $\quad$ Figures 1(a \& b) were adapted from Yuandong, Zhan and Tung (2006), How Individual differences Influence Technology Usage behaviour? Toward an Integrated Framework", Journal of Computer Information System, Winter 2005-2006, p.52.

One interesting finding by Howcroft and Hamilton (2005) who carried out a study on "customer involvement and interaction in retail banking", is that people who are both earning more income and highly educated are likely to demonstrate confidence when using financial services. In this present study therefore, it is theorized that age, IT literacy, income, place of training and educational level may have profound influence on the characteristics of a person and hence level of IT adoption (Chang and Kung, 2010).

\section{Innovation's Adoption Process}

Adoption is an individuals' decision to become a regular user of a product. The focus of adoption process is the stages through which an individual consumer passes while arriving at a decision to try or not to try or to continue or discontinue using a new product. Rogers (1995), Schiffman, Kanuk and Hansen (2012), Kautz and Larsen (2012), Kotler and Keller (2013), Schiffman, Paladino and Carlson (2013) all agree that consumers move through five stages in arriving at a decision to purchase or reject a new product. The stages are: awareness; interest; evaluation; trial and adoption. The above adoption process model is insightful in its simplicity; nonetheless, it does not adequately acknowledge that there is quite often a need or problem-recognition stage that a consumer faces before acquiring an awareness of potential options or solutions. Another glaring lapse is the inadequate provision for the possibility of evaluation and rejection of a new product or service after each stage, especially after trial. The researcher is of the view that an enhanced adoption model, to incorporate these observed lapses and many more, might be necessary. It should be noted that the adoption of some products (e.g. high or low heel shoes) may have minimum consequences whereas the adoption of other innovation (such as car, waterbed, helicopter) may lead to major behavioural and lifestyle change.

\section{Research Methodology}

This study was conducted in the fourteen (14) colleges of education located in Northwest zone of Nigeria. The zone which covers a total land area of 216,065sq km comprises seven (07) states of Jigawa, Kaduna, Kano, Katsina, Kebbi, Sokoto and Zamfara. The plan adopted for this study was a cross-sectional form of descriptive survey design. The population of this study comprised all staff members in the fourteen (14) government owned 
Colleges of Education in Northwest zone of the country. Altogether, the population of the study was 15,219 , comprising 5,845 and 9,374 academic and non-academic (administrative) staff respectively. A sample of 610, adjudged to be representative of the population, was chosen.

A combination of simple random and stratified random sampling techniques was used to select sample for this study and data was collected through the use of a self-completion structured questionnaire. The instrument was subjected to both face and content validity. Test-retest reliability and internal consistency measures were used to ensure reliability of the instrument. The result was a coefficient $r=0.84$ and a norm score of 19.06 and according to Bryman (2008), a test-retest correlation (r) of 0.80 and above implies an acceptable level of internal reliability (or temporal stability). For the internal consistency of the instrument, Cronbach's alpha reliability coefficient was computed and reliability scores greater than 0.6 were obtained. Administration of the instrument was carried out with the aid of research assistants and the retrieved copies of the questionnaire were collated and edited. Consequently, 390 usable copies of the questionnaire were serialized and numerically coded for computer processing and data analysis. Standard type of multiple linear regression model was used to test the main hypothesis of the study at 95 per cent confidence level.

\section{4. $\quad$ Findings and Discussion}

It is often believed that socio-economic characteristics of users affect their adoption of ICT services. Therefore, multiple regression model was used to determine how much change in level of IT adoption is accounted for by respondents' socio-economic characteristics (personal attributes). Specifically, the study also sought to assess the unique contribution of each independent variable to variation in the dependent variable if all other independent variables were controlled. However, the problems associated with the multiple regression model were addressed as explained below:

Outliers and Normality: According to Pallant (2001), multiple regression is very sensitive to outliers (very high or very low scores) and normality. Normality represents the difference between the obtained and the predicted dependent variable scores and such residuals should be normally distributed about the predicted dependent variable scores. From the Normal Probability plot the points (scores) lie in a reasonably straight diagonal line from bottom to top right and this suggests no major deviations from normality. Also, from the Scatterplot of the standardized residuals, scores are roughly rectangularly distributed, with most of the scores concentrated in the centre (along the 0 point) therefore, the assumption of outliers has not been violated.

Multicollinearity: This refers to the relationship among the independent variables and the presence of multicollinearity results in high standard errors for the regression coefficients. Under this situation, the most relevant variables are difficult to decide upon and such variables may be discarded incorrectly with the resultant possibility of specification bias. The first thing therefore is to make sure that the dependent variable correlates substantially with each of the independent variables and according to Pallant (2001) a correlation coefficient (r) of above 0.3 is considered substantial. In this study, none of the independent variables has a correlation of below 0.3 with the dependent variable. Also, the independent variables (socio-economic characteristics) were tested for presence of multicollinearity. Consequently, correlations between pairs of variables were computed and the resulting matrix examined for the presence of correlation coefficients that exceed 0.90 and the results show that none of the independent variables has coefficient as high as 0.90 . This implies that the assumption of multicollinearity has not been violated.

Sequel to the resolution of problem of multicollinearity in the use of multiple regression, the focus shifted to the determination of how much change in level of IT adoption is explained by the respective socio-economic characteristics and which of the independent variable exerts the most influence on the level of IT adoption (dependent variable) if other independent variables are controlled. According to the coefficient of determination $\left(r^{2}=0.784\right)$ (in table1 below), the model (all independent variables together) explained only $78.4 \%$ of the change in the level of IT adoption (dependent variable). Since $r^{2}$ and adjusted $r^{2}$ values are very similar (adjusted $r^{2}$ decreased for only 0.006 ), the regression model in this study has very good explanatory power of the dependent variable. However, the unexplained variation of $21.6 \%$ in the level of IT adoption is accounted for by other extraneous variables (factors) not included in the model (error term $=e$ ). Therefore, there is presumption that such factors could include friends' influence, user's words of mouth and life style, among others.

In testing the statistical significance of the result, the obtained F-ratio of 34.012 and significance value of $p=$ 0.000 suggested that results of the adopted regression model could have not occurred by chance and that a combination of independent variables significantly predicted dependent variable. The outcome confirmed the presence of statistically significant contribution of consumer's socio-economic characteristics to level of IT 
adoption (see table 1 below).

Table 1: Multiple Regression Analysis to test functional contribution of respondents' socio-economic characteristics to level of IT adoption

\begin{tabular}{|c|c|c|c|c|c|c|c|}
\hline Variables & $\begin{array}{l}\text { Standardized } \\
\text { Coefficients } \\
\text { (beta) }\end{array}$ & t value & $\begin{array}{l}\text { Sig. } \\
\text { value }\end{array}$ & $\mathbf{r}^{2}$ & $\begin{array}{c}\text { Adjusted } \\
\mathbf{r}^{2}\end{array}$ & F-ratio & $\begin{array}{c}\text { Sig. } \\
\text { value }\end{array}$ \\
\hline Income & -.373 & 11.181 & .000 & \multirow[b]{6}{*}{.784} & \multirow[b]{6}{*}{.790} & \multirow[b]{6}{*}{34.012} & \multirow[b]{6}{*}{.000} \\
\hline Level of Education & -.324 & 9.223 & .021 & & & & \\
\hline Access to Technology & .242 & 8.007 & .031 & & & & \\
\hline Age & -.130 & 1.721 & .041 & & & & \\
\hline Gender & .123 & 1.653 & .047 & & & & \\
\hline Ownership of Tech. & -.120 & 1.570 & .048 & & & & \\
\hline Place of Training & .042 & .807 & .631 & & & & \\
\hline Time of Training & -.030 & .731 & .941 & & & & \\
\hline Educational discipline & .023 & .650 & .847 & & & & \\
\hline Work Experience & -.020 & .574 & .748 & & & & \\
\hline
\end{tabular}

Source: Field Survey (2018)

The study also attempted to determine the contribution of each independent variable to variation in dependent variable. Therefore, the unique contribution of each of the independent variable to change in dependent variable is obtained under the Beta Standardized Coefficients (column 2 of the above table, ignoring any negative signs). From the table and in descending order of importance, "Income" has the highest statistically significant standardized coefficient $(\beta=.373, \mathrm{p}=0.000)$. Thus, the values were significant at $\mathrm{P}<0.050$. This means that "income" was the most important predictor of level of IT adoption, when the contributions (influences) made by all other independent variables in the model are controlled. Based on this result, a one-unit increase in the "Income" would most likely result to 37.3 per cent increase in the overall level of IT adoption, other socioeconomic characteristics held constant. This was followed by "level of education" with a beta of $0.324, p=0.021$ (also significant at $\mathrm{p}<0.050$ ). This equally means that a one-unit increase in "level of education" would most likely result to 32.4 per cent increase in the overall level of IT adoption. Next was "access to technology" with a beta of $0.242, p=0.031$ (significant at $\mathrm{P}<0.050$ ). This equally means that a one-unit increase in "level of education" would most likely result to 24.2 per cent increase in the overall level of IT adoption. The unique individual contribution of "age" was also significant with a beta of $0.130, p=0.041$, which means that a one-unit increase in "age" would most likely result to 13 per cent increase in the overall level of IT adoption. Next to "age" in the decreasing order of significant contribution was "gender" with a beta of 0.123 and $p=0.047$. This equally means that a one-unit increase in "gender" would most likely result to 12.3 per cent increase in the overall level of IT adoption. This was equally followed by "ownership of technology" with a beta of $0.120, p=$ 0.048 (significant at $\mathrm{P}<0.050$ ). This equally means that a one-unit increase in "ownership of technology" would most likely result to 12 per cent increase in the overall level of IT adoption.

The individual contribution made by the other socio-economic characteristics to variation in level of IT adoption was not statistically significant at $\mathrm{p}>0.050$. Specifically, "place of training" made statistically insignificant singular contribution to explaining the variation in level of IT adoption with a beta value of 0.042 and a significance value of $\mathrm{p}=0.631$ (not significant at $\mathrm{P}>0.050$ ), meaning a one-unit increase in "place of training" would only lead to 4.2 per cent increase in the level of IT adoption. Also, "time of training" was found to make insignificant individual contribution to variation in level of IT adoption with a beta value of 0.030 and a significance value of $\mathrm{p}=0.941$ (not significant at $\mathrm{P}>0.050$ ), meaning a one-unit increase in "time of training" would only lead to 3 per cent increase in the level of IT adoption. Last on the table are the socio-economic attributes of "educational orientation/discipline" with a beta value of .023 and "work experience" with a beta value of .020 respectively (see table 1 above).

It is evident from the above results that six (6) socio-economic attributes, namely income, level of education, access to technology, age, gender and ownership of technology made statistically significant unique contribution to explaining change in level of IT adoption. However, since all the variables were considered together, the 
deletion of one independent variable (even though not significant) can affect the significance levels of other independent variables (Leech, Barett \& Morgan, 2005). Therefore, multiple regression model in this research gives adequate and significant result, meaning that the six (6) independent variables listed above can be used as significant predictors of level of IT adoption. Generally, this finding partially supported Rogers' proposition that early adoption of technological innovation is a function of increasing education and socio-economic status

This finding confirmed the submissions of Frias-Martinez and Virsesa (2012) that there is strong relationship between socio-economic factors and cell phone usage. Later researchers, such as Ajiboye, Tella, Adu and Wojuade (2013); Agyekum, Haifeng and Agyelwaa (2015) and Jiriko, Obianuko and Jiriko (2015) equally confirmed that users' ages, income, educational levels and access to technology have profound influence on their level of innovation perception and adoption. The finding of this study also corroborates a recent study by Sikundla, Mushunje and Akinyemi (2018) where it was confirmed that there is a strong association between socio-economic variables and adoption of mobile cell phone. However, this finding is at variance with AmuaSekyi and Asare (2016) who concluded that age and gender of staff do not influence their level of IT adoption.

\section{Conclusion}

Arising from the above findings, it is hereby concluded that socio-economic variables have significant influence on IT adoption and each of income, level of education, access to technology, age, gender and ownership of technology has significant influence on the level of IT adoption. In other words, income, level of education, access to technology, age, gender and ownership of technology are predictors of level of ICT adoption. However, socio-economic variables such as place of training, time of training, educational discipline and work experience do not have significant individual influence on the level of IT adoption.

\section{Recommendation}

For a realistic and meaningful diffusion of ICT, access to ICT facilities is a prima facie necessity. Accessibility would be more meaningful and convenient if staff members are encouraged to possess their own personal desktop and laptop. Therefore, it is recommended that institutional heads should consider sales, training and maintenance agreement with hardware producers and software developers for the benefits of staff members. Implementation of such type of agreement should take into cognizance the notable socio-economic variables that influence ICT adoption. Employees should be encouraged to have access to expertise in data processing, graphics and publishing packages. Sponsorship to attend workshops and seminars in specialized software should be provided for staff members in order to broaden their knowledge for greater expertise.

It is also recommended that institutional culture which values and rewards ICT innovation should be embraced by school administrators. This would serve as encouragement to innovators and a challenge to 'laggards'. It is recommended that Local Area Network (LAN) be adopted in addition to INTERNET facility in order to expand the access to information search and dissemination within the educational institutions.

\section{References}

Agarwal, R. \& Prasad, J. (1999). "Are Individual differences germane to the acceptance of new Information Technology?”, Decision Sciences, 30(2),361-4.

Agyekum, C. K., Haifeng, H. \& Agyelwaa, A. (2015). "Consumer Perception of Product Quality", Microeconomics and Macroeconomics, 3(2), 25-29.

Ajiboye, O. A., Tella, A., Adu, E. O. \& Wojuade, J. I. (2013). "Stakeholders' Perception of the impact of GSM on Nigeria rural economy: Implication for an Emerging Communication Industry", Journal of Information Technology Impact, 7(2), 143-144.

Ajzen, I. \& Fishbein, M. (1980). Understanding Attitudes and Predicting social behaviour, New Jersey: Englewood Cliffs, Prentice Hall.

Ajzen, I. (1985). From intentions to actions: a theory of planned behaviour, In: J. Kuhl \& J. Beckmann (eds), Action control: from cognition to behaviour, New York: Springer-Verlag.

Amua-Sekyi, E. T. \& Asare, Y. (2016). "A Survey of Information Communication Technology Literacy among Lecturers", Information and Knowledge Management, 6(8), 1-7. (accessed on August, 2018). 
Ani, O. E.; Esin, J. E. \& Edem, N. (2006). “Adoption of Information and communication technology (ICT) in academic libraries: a strategy for library networking in Nigeria”. The Electronic Library, 23(6),701-708.

Bryman, A. (2008). Social Research Methods, New York: Oxford University Press Inc.

Chang, H. H. \& Kung, C. (2010), “An empirical investigation of Internet banking in Taiwan”, Global Journal of business Research, 4(2), 40.

Chuttur, M. Y. (2009). "Overview of the Technology Acceptance Model: Origins, Developments and Future Directions", Indiana University, USA . Sprouts: Working Papers on Information Systems, 9(37).

Darmawan, I. G. N. (2013). “Adoption and implementation of information technology in Bali's local government: a comparison between single level path analysis using PLSATH 301 and AMOS 4 and multilevel path analyses using MPLUS 201”, International Education Journal, 2(4), 100-3.

Davis, F. D. (1989). "Perceived usefulness, perceived ease of use and user acceptance of information technology”. MIS Quarterly, 15(3), 319-40.

Davis, F. D. Bagozzi, R. P. \& Warshaw, P. R. (1989). "User Acceptance of Computer Technology: A comparison of two theoretical models", Management Science, 35(8), 982-3.

Federal Government of Nigeria, FGN (2004). The Obasanjo Reforms: Information Technology, Abuja: Federal Ministry of Information and National Orientation.

Frias-Martinez, V. \& Virsesa, J. (2012). Relationship between socio-economic factors and Cell phone Usage, Atlanta, GA, USA: In ICTD.

Jiriko, R. K., Obianuko, J. C. \& Jiriko, K. G. (2015). "Socio-economic factors affecting ICT utilization by Youths in Fish farming in Kaduna state, Nigeria", Global Journal of Agricultural Research, 3(4), 12-22. (accessed on 12 October 2018).

Howcroft, B. \& Hamilton, R. (2005). "Customer involvement and interaction in retail banking: an examination of risk and confidence in the purchase of financial products", Journal of Services Marketing, 21(7), 481.

Kautz, K. \& Larsen, E. A. (2012). "Diffusion theory and practice: disseminating quality management and software process improvement innovations", Information Technology and People, MCB University Press, 13(1), 11-26.

Kotler, P. \& Keller, K. L. (2013). Marketing Management, 14th edition, New Delhi: Prentice Hall of India Private Ltd.

Lakhanpal, B. (2004). “Assessing the factors related to microcomputer usage by middle managers: International Journal of Information Management, 14(1), 39.

Leech, N. L., Barret, K. C. \& Morgan, G. A. (2005). SPSS for Intermediate Statistics: Use and Interpretation, 2nd ed., New Jersey: Lawrence Erlbaum Associates Publishers.

Lii, S. S. (2013). "Electronic newspaper and its adopters: examining the factors influencing the adoption of electronic newspapers in Taiwan". Telematics and Informatics, 20(2), 35-40.

Oketunji, I.; Daniel, J. O.; Okojie, V. O. \& Abdulsalam, R. (2012). “40 years of library and information service to the nation". A compendium of papers presented at $40^{\text {th }}$ National Annual Conference and AGM of Nigerian Library Association, Lagos, 3-11.

Omoniwa, M. A. (2001). "The computerization of Kashim Ibrahim Library of Ahmadu Bello University, Zaria 1972 - 2001”. Nigerian Libraries, Journal of the Nigerian Library Association, 35(1), 15-22.

Pallant, J. (2001). SPSS Survival Manual: A step by step guide to data analysis using SPSS for Windows. Maidenhead - Berkshire: Open University Press.

Rogers, E. M. (1995). Diffusion of Innovations, $4^{\text {th }}$ edition, New York: Free Press Ltd.

Schiffman, L. G. \& Kanuk, L. L. (2010). Consumer Behaviour, 11 $1^{\text {th }}$ edition, Delhi - India: Pearson Education Inc.

Schiffman, L. G., Kanuk, L. L. \& Hansen, A. (2012). Consumer Behaviour: A European outlook, $2^{\text {nd }}$ edition, Harlow-England: Pearson Financial Times.

Schiffman, L. G., O’Cass, A. Paladino, A. \& Carlson, J. (2013). Consumer Behaviour, $6^{\text {th }}$ edition, Frenchs Forest-Australia: Pearson Education. 
Sikundla, T., Mushunje, A. \& Akinyemi, B. E. (2018). "Socioeconomic drivers of mobile phone adoption for marketing among smallholder irrigation farmers in South Africa", Cogent Social Sciences, (4), 1-12.

Venkatesh, V. \& Davis, F. D. (2010). “A Theoretical Extension of the Technology Acceptance Model: Four Longitudinal Field Studies", Management Science, 45(2), 186. (accessed 29 December, 2018).

Yuandong, Z. \& Tung, K. (2006), How Individual differences Influence Technology Usage behaviour? Toward an Integrated Framework", Journal of Computer Information System, Winter 2005-2006, 52. 